\title{
極值統計解析による最大き裂長さの推定における 抽出面積と分割数
}

一分布形によらない推定精度の評価—十

松 村 隆* 市川昌 弘*

\author{
Suitable Sample Area and Number of Division in Estimation of \\ Maximum Crack Length by Extreme Value Analysis \\ - Evaluation of Estimation Accuracy Independent \\ of Distribution Forms -
}

by

Takashi MATSUmURA* and Masahiro ICHIKAwA*

In the estimation of maximum crack length in a structural component by the statistics of extremes, one encounters the problem of how to choose the sample area $S$ (the ratio of the sample area to the whole area) and the number of division $m$. In a previous paper, the present authors showed that the root mean squared error of the estimated value, $\sqrt{V\left(\hat{X}_{\max }\right)}$ can be approximated by a linear function of $\log S$ for the case when individual crack lengths follow an exponential distribution. In the present paper, by conducting theoretical analysis and Monte Carlo simulation, it is shown that $\sqrt{V\left(\hat{X}_{\max }\right)} / \sigma$ can be approximated by a linear function of $\log T$ regardless of the distribution forms of individual crack lengths, where $\sigma$ is the variance of the double exponential distribution which the largest crack length in each elemental area follows, and $T(=m / S)$ is the return period. It is also shown that $\sqrt{V\left(\hat{X}_{\max }\right)} / \sigma$ by Monte Carlo simulation is $1.1 \sim 1.9$ times larger than that by the theoretical analysis. The causes for this difference are discussed.

Key words : Reliability, Maximum crack length, Remaining life, Extreme value analysis, Monte Carlo simulation

\section{1 緒言}

構造物の安全性，信頼性を確保するために，構造物の 損傷状況を把握し，余寿命を推定することは重要である. 腐食余寿命の推定に対しては極值統計解析の適用が以前 から行われているが, 近年, 疲労余寿命の推定方法とし ても極值統計解析の適用が研究されている.

疲労の場合には，構造物の表面に存在する分布き裂の 一部分を抽出し，これより構造物に存在する最大き裂長 さの推定を行う.すなわち, Fig. 1(a)のように全面積 $A$ の中に面積 $S A(S<1)$ を抽出し, これを $m$ 個の要素面 積に等分して, 各要素面積中の最大き裂長さを測定し, この測定值に適当な極值分布をあてはめて, 全面積 $A$ の中の最大き裂長さを推定する（なお， $m$ 個の要素を Fig. 1 (b)のように離れた場合にとっても同じである). この手法を適用する際, 問題となるのが抽出面積率 $S$ と分割数 $m$ の決め方である.これらは, 最大き裂長さ の推定精度に影響を与えるパラメータであるが，その決 定の指針は得られていない.

著者らは,この問題について検討を行ってきた。いま 全面積中の最大き裂長さを $X_{\max }$ とし, その推定值を $\hat{X}_{\max }$ とすると, $\hat{X}_{\max }$ の平均二乗誤差の平方根 (Root
Mean Squared Error ; RMSE) $\sqrt{V\left(\hat{X}_{\max }\right)}$ は推定精度の 一つの尺度である. $\sqrt{V\left(\hat{X}_{\max }\right)}$ は推定值と真值の差の二 乗平均の平方根, すなわち

$$
\sqrt{V_{9}\left(\widehat{X}_{\max }\right)}=\left[E\left\{\left(\widehat{X}_{\max }-X_{\max }\right)^{2}\right\}\right]^{1 / 2}
$$

である．前報では，き裂長さの原分布が指数分布の場合 に対して, $\sqrt{V\left(\hat{X}_{\max }\right)}$ の值を理論式およびモンテカルロ シミュレーションにより求め, $\sqrt{V\left(\hat{X}_{\max }\right)}$ が $\log S$ の一 次式で近似できることを見いだした．前報のこの結果よ $\eta, \sqrt{V\left(\widehat{X}_{\max }\right)}$ と二重指数分布の標準偏差 $\sigma$ の比 $\sqrt{V\left(\hat{X}_{\max }\right)} / \sigma$ はき裂長さの原分布の形に関係なく, log $S$ の一次式で近似できることが予想される，なぜなら ば指数分布の場合， $\sigma$ は $S$ や $m$ にあまり影響を受けな いからである。

本報でははじめに，上記の予想の妥当性をしらべる. ただし，再帰期間（全面積と要素面積の比）を $T$ とす ると, $S=m / T$ の関係より, $\log S$ の一次式は $\log T$ の一次式ともなるので, 本報では $\sqrt{V\left(\hat{X}_{\max }\right)} / \sigma$ と $\log S$ の関係の代わりに, $\sqrt{V\left(\widehat{X}_{\max }\right)} / \sigma$ と $\log T$ の関係をしら べた。つぎに，原分布が指数分布の場合について， $\sqrt{V\left(\hat{X}_{\max }\right)} / \sigma$ の值をモンテカルロシミュレーションによ り詳しく求め, 理論值と比較し, 両者がどれくらい違う

$†$ 原稿受理 平成 6 年 7 月 8 日 Received July 8, 1994

* 正 会 員 電気通信大学機械制御工学科 $=182$ 調布市調布ヶ丘, Dept. of Mech. \& Control Eng., Univ. of Electro-Communications, Chofugaoka, Chofu, 182 


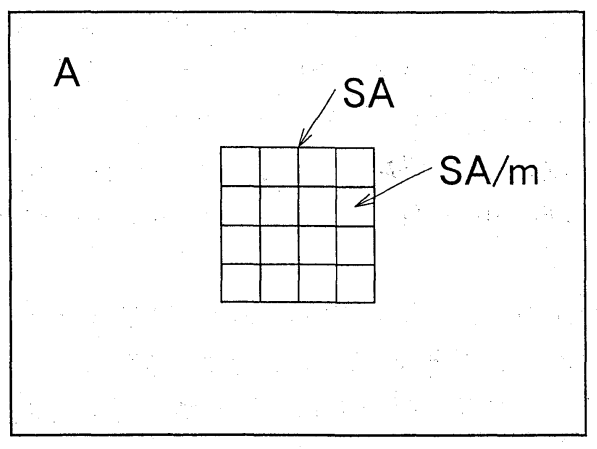

(a) Example 1.

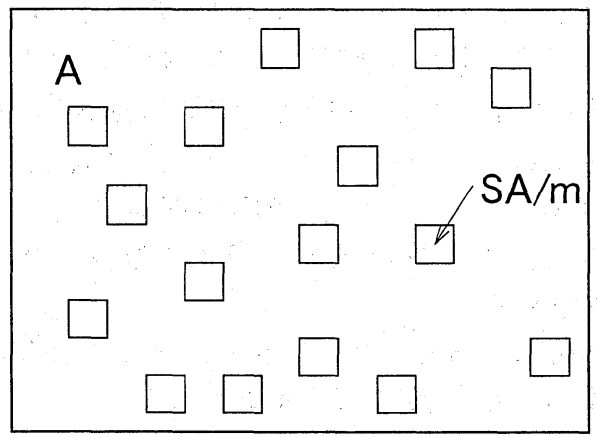

(b) Example 2 .

Fig. 1. Sample area divided into $m$ elemental areas.

か, また，その違いの原因は何かを検討した.

\section{2 理論解析による $\sqrt{V\left(\hat{X}_{\max }\right)} / \sigma$ の評価}

極值統計による極值の推定は, 各要素中の最大值が近 似的に極值の漸近分布に従うということを前提にしてい る.この前提をさらに強め, 各要素中の最大值が厳密に 極值の漸近分布に従う（すなわち，各要素中の最大値は 極值の漸近分布に従う母数団からの抽出值である）と仮 定すると, $V\left(\hat{X}_{\max }\right)$ を理論的に求めることができる。い ま，極值の漸近分布として二重指数分布を考元，また直 線のあてはめを MVLUE 法で行うと, 平均二乗誤差 $V\left(\hat{X}_{\max }\right)$ は理論的には次式で与えられる。.

$V\left(\widehat{X}_{\max }\right)=$

$\left[A(m, m) \cdot y^{2}+B(m, m) \cdot y+C(m, m)\right] \cdot \alpha^{2}(2)$ ここで, $A(m, m), B(m, m), C(m, m)$ はVLUE 法 の係数.また $y$ は

$$
y=-\ln \left[-\ln \left(1-\frac{1}{T}\right)\right]
$$

であり， $\alpha$ は二重指数分布の尺度パラメータで，二重指 数分布の標準偏差 $\sigma$ と次式の関倸がある.

$$
\alpha=\frac{\sqrt{6}}{\pi} \sigma
$$

式 (2) に式(4)を代入し, $\sqrt{V\left(\hat{X}_{\max }\right)}$ と $\sigma$ の比を求める と次式となる。

$$
\begin{aligned}
& \frac{\sqrt{V\left(\hat{X}_{\max }\right)}}{\sigma}= \\
& \frac{\sqrt{6}}{\pi} \sqrt{\left[A(m, m) y^{2}+B(m, m) y+C(m, m)\right]}
\end{aligned}
$$

式（5）を用いて $\sqrt{V\left(\hat{X}_{\max }\right)} / \sigma$ を計算した．分割数 $m$ と再帰期間 $T$ の值は次のようにとった.

$m: 4,8,12,16,20,23$ 分割の 6 通り.
$T: 10000,5000,2000,1000,500,200,100,50$, 30 ( $m=20,23$ のみ), $20(m=4,8,12,16$ のみ), 10 ( $m=4,8$ のみ) の 11 通り.

計算結果は Fig. 2 のようになった．図中の直線は各分 割数 $m$ に対して最小二乗法により求めた近似直線であ り, 計算点は直線に非常によくのっており, $\sqrt{V\left(\hat{X}_{\max }\right)}$ $/ \sigma$ は $\log T$ の一次式で精度よく近似できることがわか る.

Fig. 2.より, $m=$ 一定ならば $T$ が小さいほど $\sqrt{V\left(\hat{X}_{\max }\right)} / \sigma$ は小さくなること, また $T=$ 一定ならば $m$ が大きいほど $\sqrt{V\left(\hat{X}_{\max }\right)} / \sigma$ は小さくなることがわか る.これは， $m=$ 一定なら $T$ が小さいほど，また $T=$ 一定なら $m$ が大きいほど抽出面積率 $S$ が大きくなるこ とから理解できる. Fig. 2 中の点線は $S=$ 一定の曲線で ある. これより， $S=$ 一定ならば $m$ を大きくする（す なわち，Tを大きくする）方が $\sqrt{V\left(\hat{X}_{\max }\right)} / \sigma$ は小さく なることがわかる．ただし，実際には可能な分割数 $m$ には上限がある，なぜなら， $m$ をあまり大きくすると 一要素面積中のき裂数が少なくなり，極值統計解析の前 提が成立しなくなるからである.

つぎに, $\sqrt{V\left(\hat{X}_{\max }\right)} / \sigma$ を $\log T$ の一次式で近似したと きの係数を $m$ の関数で表す. Fig. 2 において個々の分 割数 $m$ に対して最小二乗法により求めた近似直線の傾 きを $a$ ，切片を $b$ とし，Fig. 3，4にこれらをロ印で示 す。図中の曲線は，各種関数のあてはめを行い，相関係 数が最も大きくなった関数を用いて描いた曲線であり,

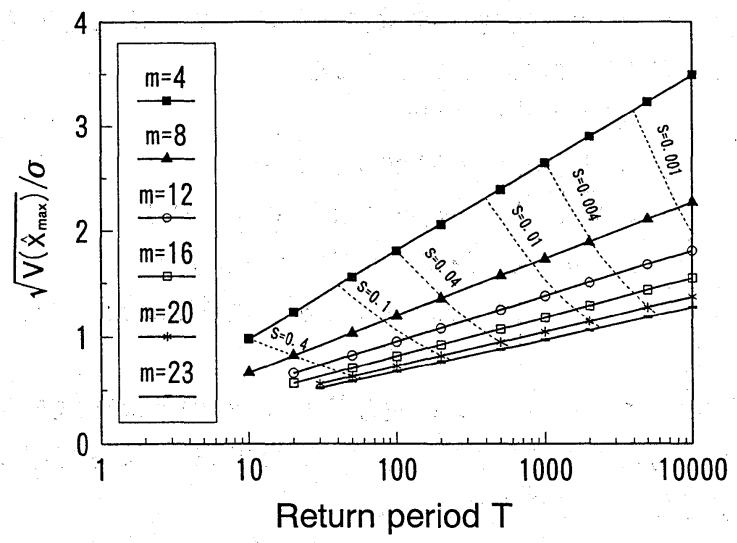

Fig. 2. Relationship between $\sqrt{V\left(\hat{X}_{\max }\right)} / \sigma$ and $T$ (by theory)

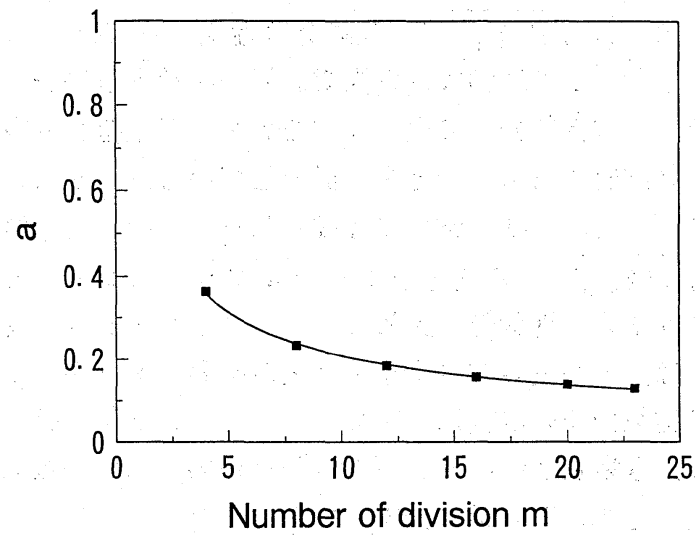

Fig. 3. Relationship between $a$ and $m$ (by theory). 


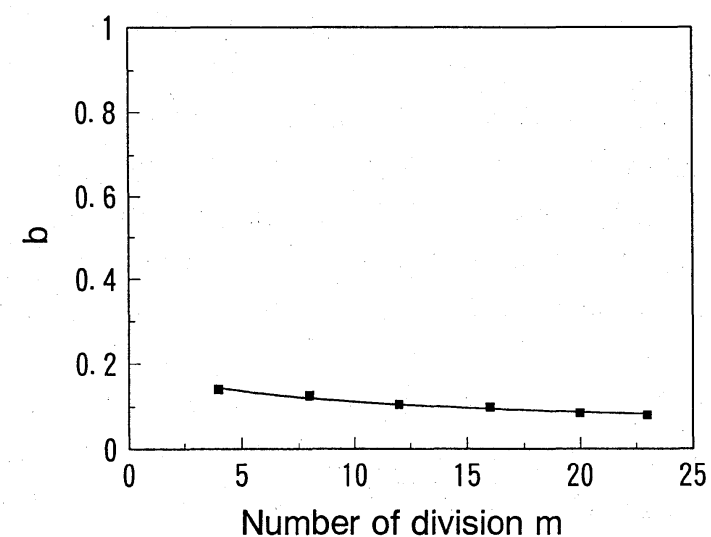

Fig. 4. Relationship between $b$ and $m$ (by theory).

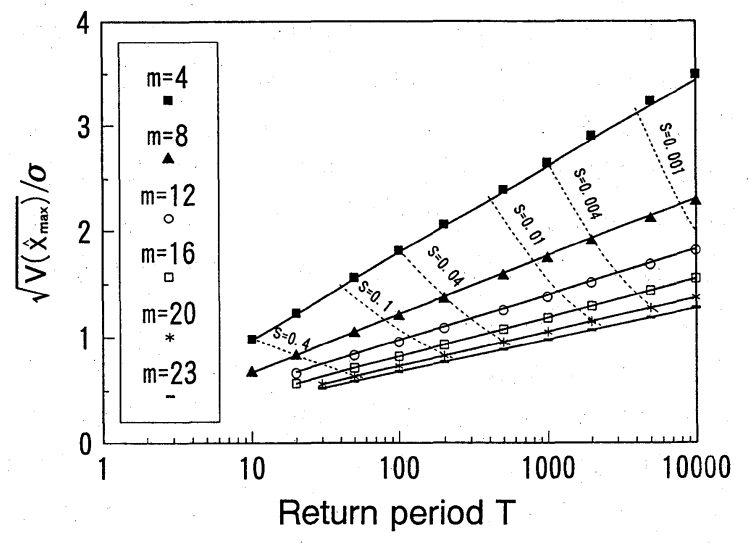

Fig. 5. Comparison between Eq. (5) and Eq. (8).

$a, b$ の各点は, 曲線に非常によくのっていることがわ かる.この関数は次式で表される.

$$
\begin{aligned}
& a=1.85919 \times m^{-0.588452} \\
& b=0.192570-0.0818389 \times \log m
\end{aligned}
$$

よって $\sqrt{V\left(\hat{X}_{\max }\right)} / \sigma$ の近似式は, 式 (6), (7)より

$\sqrt{V\left(\hat{X}_{\max }\right)} / \sigma=\left(1.85919 \times m^{-0.588452}\right) \times \log T$ $+0.192570-0.0818389 \times \log m$

となる.

Fig. 5 は, 式 (5)による理論值と式 (8) の近似直線を比 較したものである. 図より, 式 (5) は式 (8)によって精度 よく近似できることがわかる.

\section{3 モンテカルロシミュレーションによる $\sqrt{\boldsymbol{V}\left(\hat{\boldsymbol{X}}_{\max }\right)} / \sigma$ の評価}

$3 \cdot 1$ シミュレーションの目的

2 章では $\sqrt{V\left(\hat{X}_{\max }\right)} / \sigma$ の值を理論式 (式 (5)) により 計算した. この理論式は各要素面積中の最大き裂長さが 正確に二重指数分布に従う（すなわち, 二重指数分布か らの抽出值である）ことを前提としている. しかし，実 際には，この前提は厳密には成立しない. そこで本章で は $\sqrt{V\left(\hat{X}_{\max }\right)} / \sigma$ の值をモンテカルロシミュレーション により求め, 理論值と比較する. シミュレーションを行 うには，き裂長さの原分布を与える必要があるが，ここ では指数分布の場合についてシミュレーションを行う. なお，き裂長さの原分布が指数分布の場合には，最大值 の漸近分布は二重指数分布になる。

$3 \cdot 2$ シミュレーションの方法
シミュレーションは計算機により次の手順で行った.

(1) き裂を発生させる全面積を, あらかじめ再帰期間 $T$ の数で分割しておく. 例えば, 再帰期間 $T$ が 10000 の場合, 縦に 100 , 横に 100 として格子状に分割する (格子の合計 10000 個).この一つの格子が一要素面積 に相当する.

(2) 全面積に，き裂総数 $N$ の数だけき裂を発生させ る. き裂がどの要素面積に入るかは一様乱数により決め る.また，き裂長さは指定した分布型に従うものとする.

(3) 発生させた $N$ 個のき裂の最大き裂長さ $X_{\max , i}(i$ は $i$ 回目のシミュレーションを意味する）を求める.

(4) 全面積の中から分割数 $m$ 個分の要素面積を一様 乱数によって抽出する. 抽出した各要素面積の中の最大 き裂長さ $\hat{X}_{e \max , j}(j=1 \sim m)$ を求め, $\hat{X}_{e \max , j}$ を二重 指数確率紙にプロットする. MVLUE 法を用いて直線 をあてはめ, 再帰期間 $T$ から最大き裂長さの推定值 $\widehat{X}_{\max , i}$ を求める.

(5) 同時に, あてはめた二重指数分布の標準偏差 $\sigma_{i}$ を計算する. $\sigma_{i}$ は次式により計算される.

$$
\sigma_{i}=\frac{\pi}{\sqrt{6}} \sum_{j=1}^{m} b_{j}(m, m) \cdot \hat{X}_{e \max , j}
$$

$b_{j}(m, m)$ は, MVLUE 法の係数である.

(6) (1)〜(5)を $M(=10000)$ 回繰返す.

(7) $\sqrt{V\left(\widehat{X}_{\max }\right)}$ および $\sigma_{i}$ の平均值 $\sigma$ を次式より計算 し, これより $\sqrt{V\left(\hat{X}_{\max }\right)} / \sigma$ を求める.

$$
\begin{aligned}
& \sqrt{V\left(\hat{X}_{\max }\right)}=\sqrt{\frac{\sum_{i=1}^{M}\left(\hat{X}_{\max , i}-X_{\max , i}\right)^{2}}{M}} \\
& \sigma=\frac{\sum_{i=1}^{M} \sigma_{i}}{M}
\end{aligned}
$$

シミュレーションで用いた分割数 $m$, き裂総数 $N$, 再帰期間 $T$ の值と, その他の条件を以下に示す.

(1) き裂長さの分布形 (原分布): 平均長さ $1 \mathrm{~mm}$ の 指数分布.

(2) 分割数 $m: 4,8,12,16,20,23$ 分割の 6 通り.

(3) き裂総数 $N: 1000,10000,100000$ の 3 通り.

(4) 再帰期間 $T: 10000,5000,2000,1000,500$, $200,100,50,30$ ( $m=20,23$ のみ), $20(m=4$, $8,12,16$ のみ), $10(m=4,8$ のみ) の 11 通り.

(5) 一要素面積の平均き裂数 $n: 10$ 以上.

(6) 繰返し数 $M: 10000$ 回.

一要素面積中の平均き裂数 $n$ について $n \geq 10$ という 条件を設けたのは， $n$ がある程度以下になると各要素面 積中の最大き裂長さの分布が極值分布で近似できなくな り，極值統計解析の手法の前提が成立しなくなるためで ある. 今回のシミュレーションでは, 各要素面積中の最 大き裂長さ $\hat{X}_{e \max , j}$ を二重指数確率紙にプロットした時 に相関係数をあわせて計算し（シミュレーションの手順 (4), シミュレーション終了後相関係数の平均值を求め た. 本論文では, 相関係数の平均值が 0.9 以上の場合を 二重指数分布にほぼ従っているとした. その結果， $n$ $\gtrsim 10$ とすれば，相関係数の平均值が 0.9 以上となるこ 
とがわかった．上記の条件を満たす組合わせのシミュレ ーションを行い, 分割数 $m$ と再帰期間 $T$ に対する $\sqrt{V\left(\hat{X}_{\max }\right)} / \sigma$ の值の計算を行った.

\section{$3 \cdot 3$ 結果と考察}

シミュレーションの結果を, き裂総数 $N=1000$, 10000,100000 の各場合に対して Fig. 6 (a)～(c) に示す. Fig. 6 より次のことがわかる.

(1) 再帰期間 $T$ と分割数 $m$ のそれぞれが等しい場合, $\sqrt{V\left(\hat{X}_{\max }\right)} / \sigma$ はき裂総数 $N$ にほとんど依存しない（Fig. 6 の (a), (b), (c)の 3 つの図を重ねてみると， ほとんど完 全に一致する).

(2) $\sqrt{V\left(\hat{X}_{\max }\right)} / \sigma$ と $T$ の関係はシミュレーションの 場合も片対数グラフ上でほとんど直線となる.

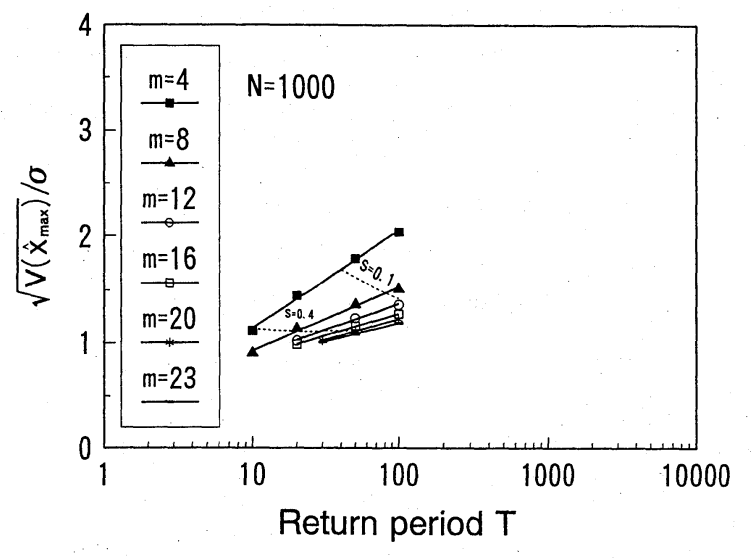

(a) $N=1000$.

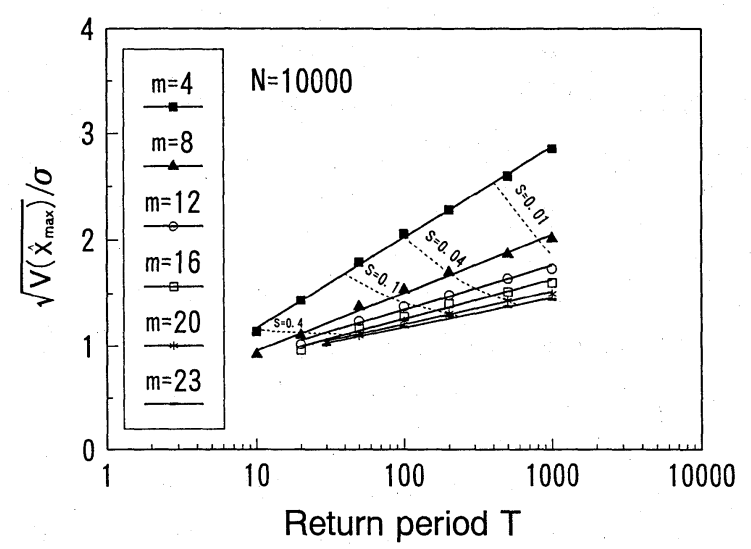

(b) $N=10000$.

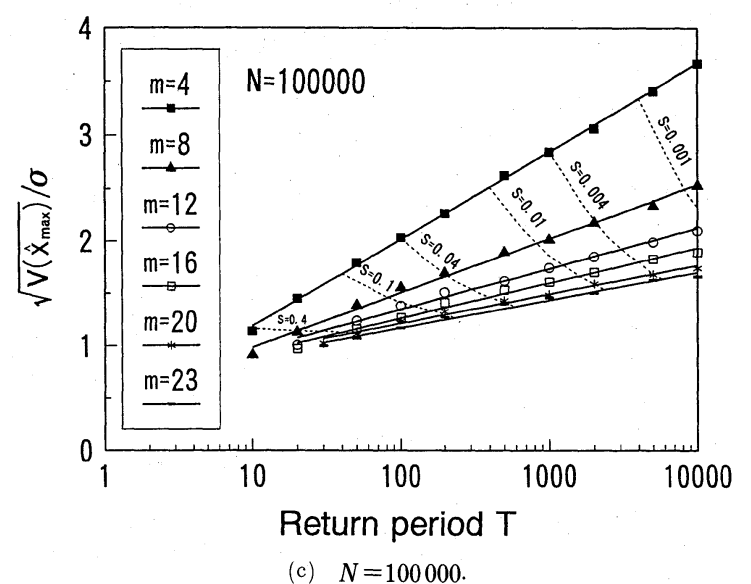

Fig. 6. Relationship between $\sqrt{V\left(\hat{X}_{\max }\right)} / \sigma$ and $T$ (by simulation).
つぎに，前述の理論式による結果 (Fig. 2) を Fig. 6 と比較すると, 次のことがわかる.

(1) シミュレーションの結果と理論式による結果は傾 向的によく似ている.

(2) $\sqrt{V\left(\hat{X}_{\max }\right)} / \sigma-\log T$ のグラフの傾きは, 同じ $m$ に対してシミュレーションと理論とでほぼ等しい.

(3)しかし, 定量的にみると, $\sqrt{V\left(\hat{X}_{\max }\right)} / \sigma$ はシミュ レーションの值の方が理論值よりも大きく，前者は後者 の約 $1.1 \sim 1.9$ 倍である.

上記 (3) の違いは重要であるので, その原因を考察す る. 標準偏差 $\sigma$ について理論解析とシミュレーション の結果を Table I に示す.この表から，理論解析および シミュレーションによる $\sigma$ の值は, ほほ等しくなって いることがわかる.よって，理論解析とシミュレーショ ンとで $\sqrt{V\left(\hat{X}_{\max }\right)} / \sigma$ の值が異なる原因は， $\sigma$ ではなく $\sqrt{V\left(\hat{X}_{\max }\right)}$ にあることがわかる.

Table I. $\sigma$ by theory and simulation.

\begin{tabular}{c|c|c}
\multicolumn{2}{c|}{$(N=100000, m=4)$} \\
\hline$T$ & $\begin{array}{c}\sigma \\
\text { Theory }\end{array}$ & $\begin{array}{c}\sigma \\
\text { Simulation }\end{array}$ \\
\hline 10000 & 1.24 & 1.28 \\
\hline 5000 & 1.26 & 1.28 \\
\hline 2000 & 1.27 & 1.28 \\
\hline 1000 & 1.28 & 1.28 \\
\hline 500 & 1.28 & 1.28 \\
\hline 200 & 1.28 & 1.28 \\
\hline 100 & 1.28 & 1.28 \\
\hline 50 & 1.28 & 1.28 \\
\hline 20 & 1.28 & 1.28 \\
\hline 10 & 1.28 & 1.28 \\
\hline
\end{tabular}

つぎに $\sqrt{V\left(\hat{X}_{\max }\right)}$ の值がシミュレーションと理論とで 異なる程度を定量的にくわしく調べる. Fig. 7 (a)〜 (c) は, き裂総数 $N=1000,10000,100000$ の各場合に対して, 横軸に再帰期間 $T$, 縦軸にシミュレーションによる $\sqrt{V\left(\widehat{X}_{\max }\right)}$ の值を $\sqrt{V\left(\widehat{X}_{\max }\right)}$ の理論值で割った值 $\left(\sqrt{V\left(\widehat{X}_{\max }\right)}\right.$ (simulation) $/ \sqrt{V\left(\hat{X}_{\max }\right)}$ (theory)) をとって 示したものである. Fig. 7(a)〜 (c) より次のことがわかる.

(1) 分割数 $m$ を固定して考えた場合, 再帰期間 $T$ が 小さくなるほど $\sqrt{V\left(\hat{X}_{\max }\right)}$ (simulation) $/ \sqrt{V\left(\hat{X}_{\max }\right)}$ (theory) は大きくなる.

(2) 再帰期間 $T$ を固定して考えた場合, 分割数 $m$ が 大きくなるほど $\sqrt{V\left(\hat{X}_{\max }\right)}$ (simulation) $/ \sqrt{V\left(\hat{X}_{\max }\right)}$ (theory) は大きくなる.

(3) 再帰期間 $T$ と分割数 $m$ が等しい場合, $\sqrt{V\left(\hat{X}_{\max }\right)}$ (simulation) $/ \sqrt{V\left(\hat{X}_{\max }\right)}$ (theory) はき裂総数 $N$ にほと んど依存しない.

Fig. 8 は, 最大き裂長さの推定の一例である（き裂総 数 $N=100000$, 分割数 $m=23$, 再帰期間 $T=200$ の場 合).

図中の $\mathrm{A}$ 点は抽出面積中の最大き裂長さ，B 点は MVLUE 法によって推定された最大き裂長さである. この図のように，推定された最大き裂長さ（B 点）が 
抽出面積中の最大き裂長さ (A 点) より短くなってい る場合には，最大き裂長さの推定値は当然全面積中の 最大き裂長さより短いから, 精度よく最大き裂長さを 推定できない. 上記の例と同様のケースは, 10000 回中 に約 800 回あった。仮に，このようなケース（約 800） を除いてシミュレーションの場合の $\sqrt{V\left(\hat{X}_{\max }\right)}$ を再計算 すると 1.60 (除かない場合は 1.63) となる。また, $\sqrt{V\left(\hat{X}_{\max }\right)}$ (simulation) $/ \sqrt{V\left(\hat{X}_{\max }\right)}$ (theory) の值も 1.63 （除かない場合は 1.66）となり，理論值に近づくことが わかる。

以上のように推定された最大き裂長さが, 抽出面積中

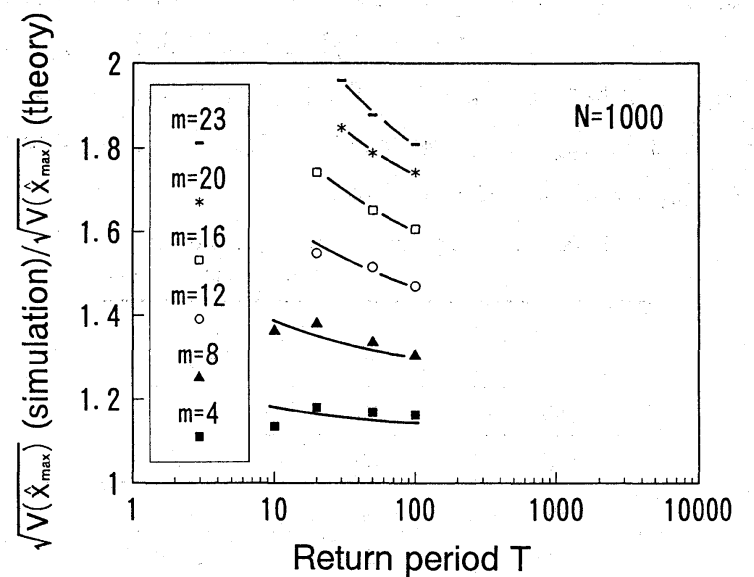

(a) $N=1000$.

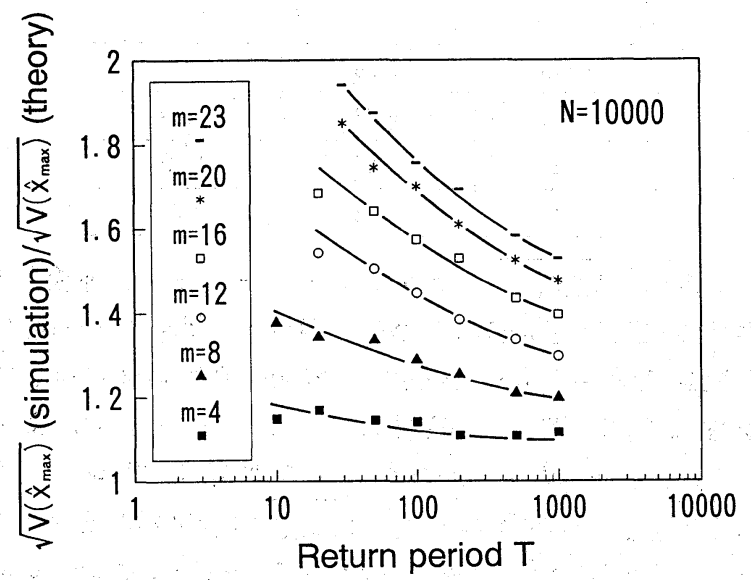

(b) $N=10000$.

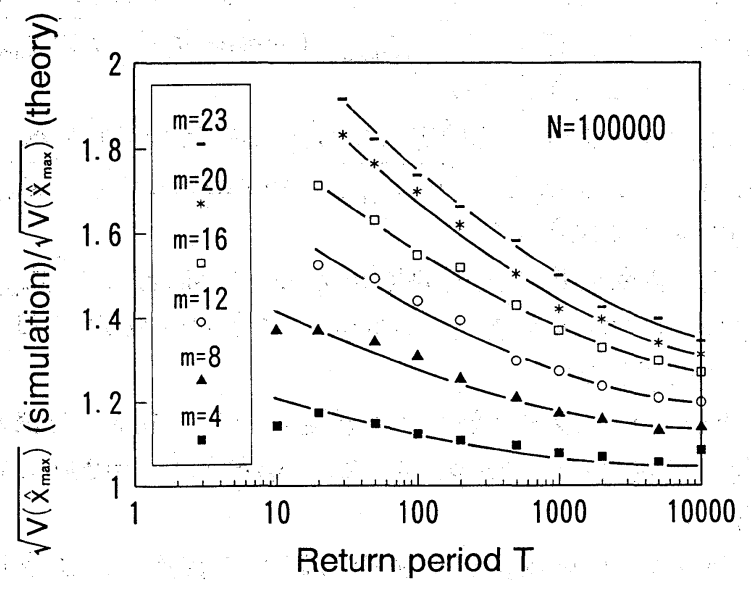

(c) $N=100000$.

Fig. 7. $\sqrt{V\left(\hat{X}_{\max }\right)}($ simulation $) / \sqrt{V\left(\hat{X}_{\max }\right)}$ (theory).

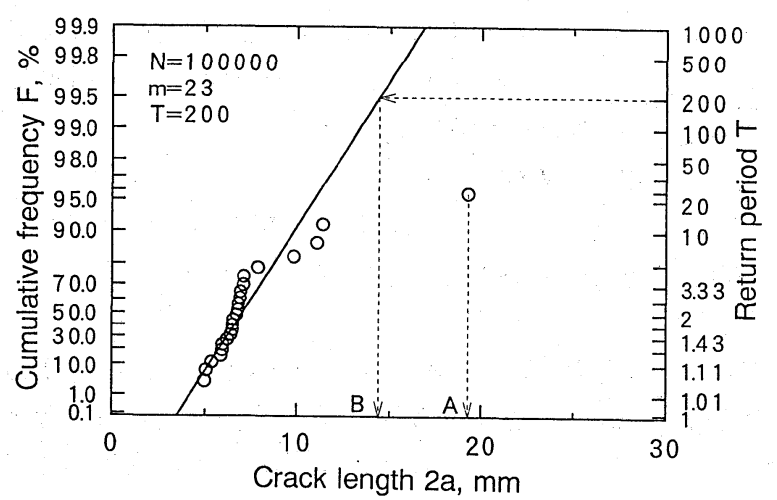

Fig. 8. Undesirable case.

の最大き裂長さより短くなるような場合は, $\sqrt{V\left(\hat{X}_{\max }\right)}$ $/ \sigma$ の理論解析では考慮されておらず, これが, シミュ レーションと理論とで $V\left(\hat{X}_{\max }\right)$ の值が異なる原因の一つ であると考えられる. また, 理論では各要素面積に同数 のき裂が存在していると仮定しているが，シミュレー ションではき裂の位置を一様乱数で決めているので, 一 般に同数とはならないことも原因の一つと考えられる.

つぎに, 2 章と同様に $\sqrt{V\left(\widehat{X}_{\max }\right)} / \sigma$ のシミュレー ションの結果を $\log T$ の一次式で近似したときの係数 を $m$ の関数で表す. 上記で述べたように再帰期間 $T$ と 分割数 $m$ が等しい場合, $\sqrt{V\left(\hat{X}_{\max }\right)} / \sigma$ はき裂総数 $N$ に ほとんど依存しないので, 傾き $a$ と切片 $b$ はき裂総数 $N$ ごとに求めるのではなく, 分割数 $m$ ごとにまとめて 最小二乗法により求めた. Fig. 9, 10 に最小二乗法によ る $a, b$ の值を四印で示す. 図中の曲線はこれに各種関 数のあてはめを行い, 相関係数が最も大きくなった関数 を用いて描いた曲線である. $a, b$ の各点は, 曲線に非 常によくのっていることがわかる. この関数は次式で表 される.

$$
\begin{aligned}
& a=2.03081 \times m^{-0.647730}(12) \\
& b=0.114928+0.385589 \times \log m \\
& \text { よって } \sqrt{V\left(\hat{X}_{\max }\right)} / \sigma \text { の近似式は, 式 }(12),(13) よ り \\
& \sqrt{V\left(\widehat{X}_{\max }\right) / \sigma=}\left(2.03081 \times m^{-0.647730}\right) \times \log T \\
&+0.114928+0.385589 \times \log m
\end{aligned}
$$

となる. Fig. 11 は, き裂総数 $N=10000$ の場合のシ ミュレーションの結果と式 (14) の近似式を比較したもの であり, シミュレーション結果は近似直線によくのって

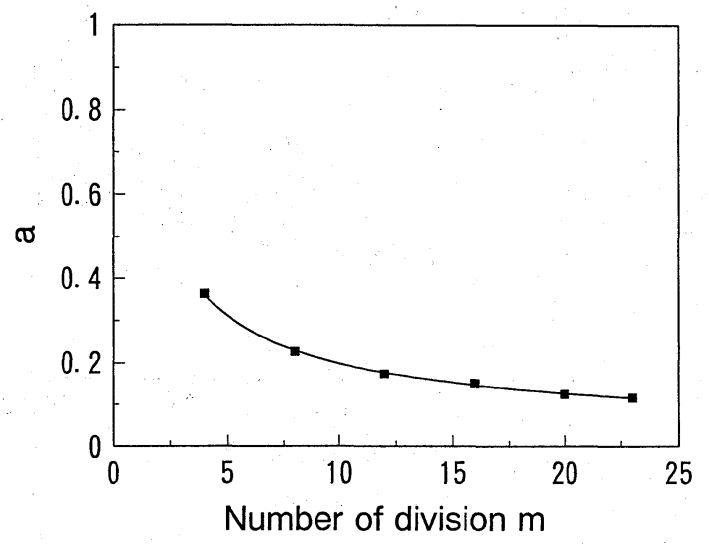

Fig. 9. Relationship between $a$ and $m$ (by simulation). 


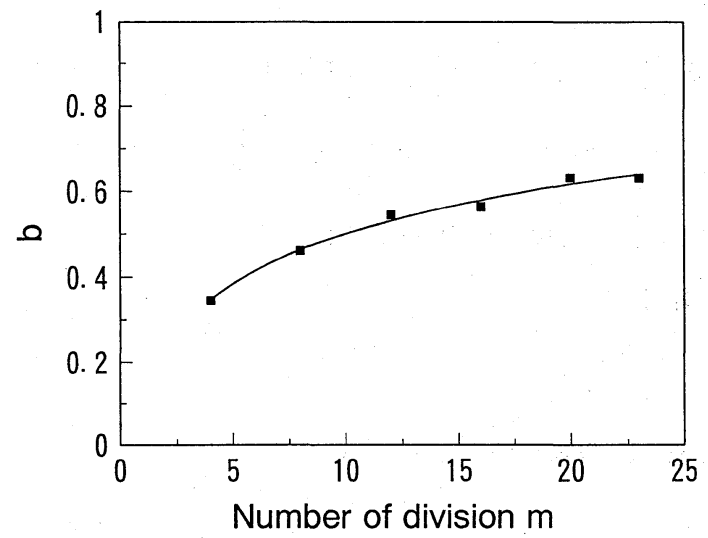

Fig. 10. Relationship between $b$ and $m$ (by simulation).

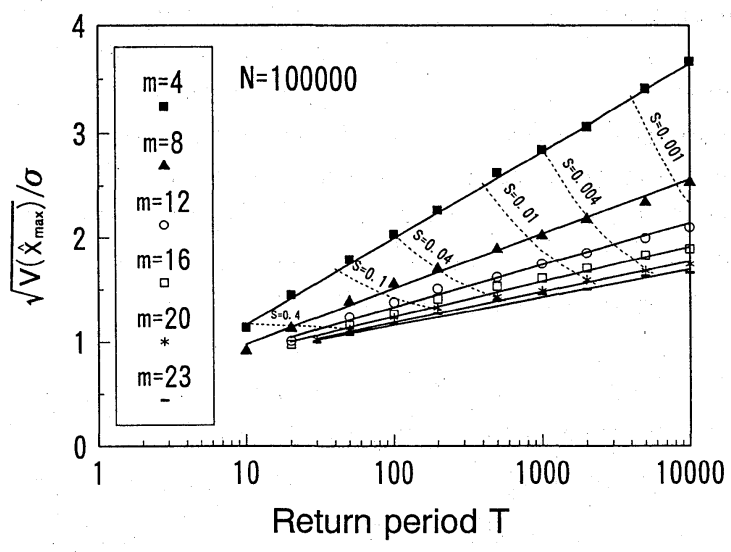

Fig. 11. Comparison of $\sqrt{V\left(\hat{X}_{\max }\right)} / \sigma$ by simulation and Eq. (14).

いることがわかる.

$$
4 \text { 結論 }
$$

最大き裂長さの推定に極值統計解析を適用する場合に, 再帰期間 $T$ と分割数 (要素面積の数) $m$ の選び方が問 題となる.この問題の解決を目的として理論解析とモン テカルロシミュレーションを行った. これより次の結論 が得られた。

（1）全面積中の最大き裂長さの推定值 $\widehat{X}_{\max }$ の平均二 乗誤差の平方根を $\sqrt{V\left(\hat{X}_{\max }\right)}$ とし，各要素面積中の最大
き裂長さが従う二重指数分布の標準偏差を $\sigma$ とすると, $\sqrt{V\left(\hat{X}_{\max }\right)} / \sigma$ の理論值は, 個々のき裂長さの原分布の形 に関係なく, $\log T$ の一次式で精度よく近似できる（ $T$ は再帰期間).この近似式は，式(8)で表される.

（2）き裂長さの原分布が指数分布の場合に対して，モ ンテカルロシミュレーションで求めた $\sqrt{V\left(\widehat{X}_{\max }\right)} / \sigma$ も $\log T$ の一次式で近似できるが, 理論式から求めた值に 比べ, 1.1〜1.9 倍大きい.この違いの原因は $\sigma$ ではな く $\sqrt{V\left(\widehat{X}_{\max }\right)}$ の值が理論解析とシミュレーションとで異 なるためである.

（3）抽出面積率 $S(=m / T)$ が同じならば，分割数 $m$ を大きくするほど（したがって，再帰期間 $T$ を大きく するほど), $\sqrt{V\left(\hat{X}_{\max }\right)} / \sigma$ は小さなる. ただし，可能 な分割数 $m$ には上限がある.

(平成 5 年 12 月 2 日 日本材料学会第 12 回材料・構造信頼性シンポジウ ムにて講演)

\section{参 考 文 献}

1 ) P. M. Azis, Corrosion, 12, 495 (1956).

2 ) 石川雄一，防食技術，29，502（1980）.

3 ) 小松正倫, 柘植宏之, 明石正恒, 正村克身, 石本裕保, “装置材料の寿命予測入門”（1984）丸善.

4 ) 今川博之, 松野健三, 材料, 38, 823 (1989).

5 ) 北川英夫, 中兽根祐司, 島崎 剛, 飯田峰昭, 材料, 34, 314 (1984).

6 ) 桜井茂雄, 宇佐美三郎, 宮田 寛, 日本機械学会論文集, A -53, 451 (1987).

7 ) 桜井茂雄, 宇佐美三郎, 梅沢貞夫, 宮田 寛, 材料, 35, 170 (1986).

8 ) M. Ichikawa, T. Takamatsu, T. Matsumura and T. Sawada, JSME Int. J. A-36, 121 (1993).

9 ) 市川昌弘, 徐勇, 日本機械学会材料力学講演会講演論 文集, No. 920-72, 714 (1992).

10) J. Lieblein, National Advisory Committee for Aeronautics, Tech. Note 3053, Washington D. C. (1954).

11) E. J. Gumbel, Statistics of Extremes, Columbia Univ. Press (1958). 